\title{
Jerzy Bagrowicz, Czy wiemy, co sprawujemy? Wtajemniczenie w liturgię Mszy świętej, Wydawnictwo Duszpasterstwa Rolników, Wloclawek 2012, ss. 239.
}

Mam przed sobą książkę niepokaźną, lecz sympatyczną w formacie i kolorystyce (zasługa Wydawnictwa Duszpasterstwa Rolników we Włocławku). Okładka lekko usztywniona matowo foliowana daje pierwsze pozytywne wrażenie na biorącym do ręki tę kolejną już pozycję dobrze znanego Autora. Publikacja ma charakter popularny i upowszechniający wiedzę potrzebną katolikom do świadomego przeżywania swojej tożsamości chrześcijańskiej i prawd wyznawanej wiary. Może posłużyć także innym, nieuprzedzonym Czytelnikom zainteresowanym problematyką religii, kultu, form i symboliki chrześcijańskiej. Oliwkowa zieleń tła pierwszej strony zewnętrznej jest rozjaśniona stylizowanym kielichem ceramicznym i złotym bochenkiem chleba na talerzu od kompletu na obrusie ,samodziałowym”, wprowadza w problematykę zapowiedzianą w tytule sformułowanym jako pytanie Czy wiemy, co sprawujemy? Poniżej dopowiedzenie, bardzo potrzebne i trafne - tytuł główny nie jest sam z siebie jednoznaczny - objaśnia, że chodzi o Wtajemniczenie w liturgię Mszy świętej. Motyw oraz tekst (projekt okładki p. Krzysztof Skrzypczyk) dobrze się uzupełniają. Czytelnik od razu wie, po co sięgnął, i jeśli jest zainteresowany liturgią, jeżeli zależy mu na wiedzy na temat Mszy świętej, sprawowanego w niej Misterium, może się spodziewać treści odpowiadającej tytułowej stronie. Ostatnia strona okładki zawiera zdjęcie Autora i krótki, lecz „,upakowany” Jego biogram. Po owej prezentacji Autora Czytelnik ugruntowuje się w pierwszym wrażeniu, że spotyka Kogoś, kto dzieli się sekretem swego serca, które karmi od 50 lat Mszą świętą. Czymże więc nas Dostojny Jubilat obdarowuje?

Zawartość omawianej książki ks. prof. zw. dr. hab. Jerzego Bagrowicza, profesora i wykładowcy w UMK w Toruniu, organizatora i pierwszego dziekana Wydziału Teologicznego tegoż Uniwersytetu, składa się z 50 jednostek tekstowych (tyle co lat kapłaństwa!), ze Wstępu i 49 „mistagogicznych katechez”, które pierwotnie były pomyślane i wygłoszone jako homilie podczas sprawowanych Mszy św. w kościele Księży Michalitów w Toruniu. Autor uzupełnił wygłoszone teksty i nadał im formę 3-4-stronicowych rozważań do poszczególnych części liturgii mszalnej. Pierwsze trzy teksty pełnią rolę wprowadzenia ogólnego do niedzielnej Eucharystii, którą zgodnie z radą Autora powinniśmy traktować jako „radosne spotkanie” z Chrystusem, a nie jako „uciążliwy «obowiązek niedzielny»”. Nauczanie Soboru Watykańskiego II, Katechizmu Kościoła Katolickiego i Jana Pawła II (List apostolski Dies Domini) podprowadza pod wezwanie w ostatnim zdaniu 
„Pójdźmy z radością na spotkanie Pana”. Po lekturze pierwszej katechezy czujemy się wciągnięci w krąg tematyki, która zaprasza do wzięcia udziału w liturgii, a jednocześnie pozwala spodziewać się w dalszych częściach równie prostego, klarownego i przystępnego przybliżania największego Misterium Kościoła, którym jest Anamnesis - Pamiątka Ostatniej Wieczerzy, Wielkiego Piątku i Zmartwychwstania Chrystusa. Tajemnica wiary, w której w niedzielnym zgromadzeniu liturgicznym uczestniczymy, odbywa się w świątyni, w kościele, nazywanym także „domem Bożym”. Jest to miejsce szczególne, wyróżniające się architekturą, stylem, wystrojem, przeznaczeniem. Dzisiejsi architekci wyznają inne przekonania niż dawni budowniczowie, co w bardzo wielu wypadkach należy ze smutkiem odnotować. Wszak i wtedy głęboko wierzącym nieporadne dzieło myśli i rąk ludzkich nie przeszkadza w spotkaniu z Chrystusem, który przychodzi spotkać się ze swoim ludem. W pejzażu miast i wsi kościół pozostaje ciągle punktem odniesienia. Chociaż nie ma w sobie potęgi (pychy?) drapaczy chmur, nie zdumiewa bogactwem wystroju pałaców i rezydencji, czy - z drugiej strony - czasem przypomina bardziej halę sportową, salę kinową, wrak łodzi (wprawdzie Chrystus nazwał swój Kościół łodzią, a apostołów rybakami), czy owczarnię (prawda, Chrystus nazwał wspólnotę swoich wyznawców owczarnią!), bryła kościoła pozostaje punktem odniesienia, bo przebywa tam Ktoś, dla Którego wszystko żyje. Autor doskonale wprowadził w klimat sacrum świątyni! tam nie można zachowywać się jak w każdym innym miejscu. Wyniesione z kościoła przeżycie duchowe ma sprawiać, że z jego pomocą świat będzie stawał się świątynią. W trzeciej katechezie Autor uświadamia sens procesyjnego porządku poprzedzającego rozpoczęcie liturgii Mszy świętej. Jest to rodzaj przygotowania do wejścia w ,głąb” misterium, które będzie się dziać niewidzialnie na ołtarzu za sprawą słów, gestów i używanych przedmiotów, gdy słowa Pisma Świętego - odczytywane i słuchane jako słowa natchnionych pisarzy i samego Chrystusa - będą nas pouczać, w co wierzyć i jak żyć, gdy wreszcie chleb i wino staną się Ciałem i Krwią Chrystusa, aby karmić naszą wiarę, nadzieję i miłość, abyśmy dojrzeli z pomocą łaski Bożej do życia wiecznego zaszczepionego w naszych sercach w sakramencie Chrztu świętego.

W dalszych katechezach: od omówienia otwierającego Mszę świętą znaku krzyża po końcowe błogosławieństwo i rozesłanie, Autor - jak dobry dydaktyk i pedagog, ale i liturg, prowadzi Czytelnika za rękę, pokazuje sens, znaczenie, często też genezę słów, gestów i przedmiotów używanych w czasie liturgii mszalnej. Poszczególne teksty, modlitwy, hymny, psalmy, wyznanie wiary, krzyż, świece, kielich, patena, szaty, kadzidło, chleb, wino i inne dary ofiarne, ołtarz, biały obrus - wszystko - okazuje się - ma głęboką treść, symbolikę. Pochodzenie tych często już bardzo uproszczonych form 
słownych, gestów i rekwizytów sięga czasów starożytnych, przedchrześcijańskich, jednak w chrześcijaństwie nabrały one całkiem nowego znaczenia i skuteczności zbawczej. Autor nawiązuje do bogatego materiału źródłowego, jakim dla liturgii jest Stary i Nowy Testament, do historii Kościoła, do życia świętych, do przykładów z życia codziennego. Nie sprawiając wrażenia naukowości, ofiaruje lektorowi prawdziwą ucztę duchową, której sekretem jest piękno i harmonia wykładu, precyzja języka i horyzonty myśli. Trudno przeprowadzać w tym miejscu szczegółową analizę poszczególnych katechez, zwrócę uwagę tylko na jeden szczegół. Pewnie to kwestia przypadku, ale w centrum znajduje się katecheza, dla której tytuł Autor zaczerpnął z 2 Tm 2, 8 „Pamiętaj na Jezusa Chrystusa”. Jeżeli Liturgia eucharystyczna, będąc Dziękczynieniem, jest też z ustanowienia Pana Jego Pamiątką („To czyńcie na moją pamiątkę" Łk 22, 19; 1 Kor 11, 24, katecheza ten wątek szerzej rozwija), to owa pamięć powinna przedłużać się we wspomnienie po Mszy świętej i powracać do tamtej chwili tęsknotą i pragnieniem pogłębienia więzi z Chrystusem, bo pamięć to powrót do serca (recordari), gdzie zapisane są najważniejsze i najdroższe przeżycia. Cóż dla chrześcijanina może być droższe niż antycypacja spotkania z Panem przychodzącym w chwale?

Na końcu Autor dołączył „Literaturę”, wykaz podstawowych dokumentów Kościoła dotyczących Liturgii, a także wybór publikacji użytecznych do pogłębienia formacji intelektualnej i świadomości religijnej Czytelnika. Gdy chodzi o dokumenty zawierające Magisterium Kościoła odnośnie do Mszy świętej może by było warto - przy wznowieniu nakładu - dla ułatwienia dotarcia do nich podać informacje co do ich polskich wydań. Myślę też, że byłoby dobrze w następnym wydaniu uwzględnić J. Ratzingera Duch liturgii, tym bardziej że otwiera to ważne dzieło polską edycję Opera omnia Benedykta XVI przygotowywaną przez środowisko KUL-owskie. Warto też wymienić ważną, nie tylko dla środowiska biblijnego, ale i liturgicznego, prawdziwą kopalnię wiedzy, a mianowicie L. Ryken, J. C. Wilhoit, T. Longman III (red.), W. Chrostowski (red. naukowy serii), Stownik symboliki biblijnej, Warszawa 2003.

Benedykt XVI wezwał katolików do podjęcia dzieła nowej ewangelizacji. Mają temu zadaniu pomóc nowe dokumenty Kościoła, kolejny Synod Biskupów, okoliczności, w jakich znalazł się dzisiejszy świat i świadomość, że przeżywamy właśnie czasy ostatnie, których sakramenty święte, a zwłaszcza Eucharystia, są zapowiedzią, ale i łaską przygotowującą spotkanie z przychodzącym Chrystusem. Może więc warto przed zakończeniem niniejszego omówienia przytoczyć fragment $\mathrm{z}$ ostatniej katechezy, będącej rodzajem osobistego apelu Autora skierowanego do uczestników niedzielnej Eucharystii: 
im bardziej poganieje świat wokół nas, im częściej prymitywni i biedni moralnie ludzie bluźnią Bogu, tym bardziej ja muszę się trzymać mocno Jezusa. Im bardziej rządzi prawo nienawiści, tym bardziej ja muszę być świadkiem miłości Boga, także wobec tych, którzy nienawidzą i bluźnią. Takie jest bowiem prawo, które dał nam Pan i nas w tych niełatwych czasach uczynił odpowiedzialnymi za zwycięstwo dobra w świecie. Jeśli złączeni miłością z Jezusem będziemy mu wierni i wierni miłości do drugiego człowieka, tym bardziej będziemy misjonarzami współczesnego świata, także naszego środowiska, w którym jesteśmy przez Boga postawieni. Świat potrzebuje miłości, naszego świadectwa, bo na tym przecież polega nowa ewangelizacja, aby ludzie ochrzczeni, którzy odeszli od Boga, zaniedbali ścieżki, które prowadzą do świątyni i przestali się modlić, dzięki świadectwu ludzi kochających Boga mogli przeżyć swoje nawrócenie. W dziele nowej ewangelizacji, do której wszyscy jesteśmy wezwani, nie chodzi tylko o to, aby chrzcić niewierzących, ale aby nawracać ochrzczonych.

I kończy Autor ostatnim wnioskiem: „Liczy się najbardziej to dobro ciche, mało znane, wypełnianie nakazu dawania świadectwa przez zwykłych ludzi, na co dzień żyjących prawdą Ewangelii. Jesteśmy z nich i pośród nich. Odnówmy w sobie świadomość chrzcielną, świadomość naszego posłania, bo to Jezus nas posyła, abyśmy nie bali się głosić Jego Ewangelii i być Jego świadkami" (s. 235-236).

Dostojny Autor i Jubilat obdarował nas - podkreślmy to jeszcze raz świadectwem swojej wiedzy, owocem wieloletniego nauczania w seminariach, z katedr uniwersyteckich, z ambony i doświadczeniem zdobytym w pierwszych latach kapłaństwa w salkach katechetycznych. Ubogacił i umocnił nas - każdy Czytelnik omawianej pozycji to zgodnie sam stwierdzi - świadectwem własnego przeżywania Mszy świętej! Autor pomaga widzieć i czytać to, co dzieje się na ołtarzu i wokół niego zanim go otoczymy i co powinno mieć miejsce później, jako przedłużenie misterium, w którym uczestniczyliśmy. Ciesząc się z pięknego podarunku, służącego pomocą w zgłębianiu i przeżywaniu Mysterium fidei, składamy Autorowi gratulacje z racji Złotego Jubileuszu Kapłaństwa, a także z racji wydania tej prawdziwej perełki, którą jest Jego podpowiedź na pełne troski pytanie kapłana i duszpasterza: Czy wiemy, co sprawujemy?, które - jak widać - odnosi także do siebie. To również świadczy, jak głęboko sam przeżywa Eucharystię. Za to świadectwo szczególnie serdecznie Autorowi dziękujemy.

\section{Stanistaw Jankowski*}

* Ks. dr Stanisław Jankowski jest wykładowcą w Wydziale Teologicznym Uniwersytetu Mikołaja Kopernika w Toruniu. 
(c) (i) $\ominus$ 